\title{
Exhibiting Galicia: Problems of Interpretation and Other Reflections on the Permanent Exhibition at the Galicia Jewish MUSEUM IN KRAKów
}

\author{
Jonathan Webber \\ (Jagiellonian University in Krakow, Poland) \\ e-mail: jonathanwebber2@gmail.com
}

Keywords: Jewish Galicia, Polish Jewish heritage, Polish Jewish museums, post-Holocaust Jewish absence, original Holocaust sites, invisible mental landscapes

\begin{abstract}
The exhibition “Traces of Memory" presents about 150 present-day large-format colour photographs of the Jewish heritage still to be seen in many different towns in that part of Galicia which is today in Poland. The exhibition is innovative in museological terms. It does not present the Jewish history of Galicia using conventional chronology; nor is it comprehensive. Rather it is divided into a simple five-part set of ideas intended to help visitors make sense of the complex, conflicting realities relating to Jewish heritage 75 years after the Holocaust: that Polish Galicia is full of the abandoned ruins of the Jewish past; it is also full of surviving fragments of pre-Holocaust times; full of places where the mass atrocities of the Holocaust took place; it is also full of post-war attempts to restore (or to abandon) sites of Jewish significance; and full of individuals, from all walks of life, contributing to a new visibility of Jewish culture in the Polish landscape.

But piecing together the present-day evidence into a coherent five-part exhibition, by assigning such socio-cultural meanings to what the photos are deemed to represent, is not a straightforward matter. How "typical" are they as illustrations of one of those five ideas? How far can one generalize on the basis of decontextualised visual evidence - architecturally typical, historically typical, socio-culturally typical? The problem is that a photograph can simultaneously have multiple meanings; and this paper includes numerous examples. Part of that is because of the cultural displacement caused by the Holocaust and its after-effects. Just as a "synagogue" marked on a tourist map may in fact no longer really be a synagogue, so too one strategy of memorialising a devastated Jewish cemetery has often been to turn it into a lapidarium - a collection of surviving tombstones. In other words, when re-presented as heritage, such places may no longer "mean" what they were originally intended to mean. So often the Jewish heritage as presented through photographs is treated as self-evident. But in fact the same place, or the same photo, may mean different things to different people: meaning may thus be a matter of emphasis and interpretation, an ambiguity which is not always made fully explicit.
\end{abstract}

\section{The nature and purpose of the exhibition}

The purpose of this article is to offer a critical comment on the permanent exhibition of the Galicia Jewish Museum in Kraków. ${ }^{1}$ That exhibition, "Traces of Memory," is based on a research project of mine, so let me start off with a few words of background.

${ }^{1}$ An earlier version of this paper was originally presented as the opening keynote lecture at a three-day conference on "Jews in Galicia," held at the Galicia Jewish Museum, Kraków, in September 2019. I am 
Together with the British photographer Chris Schwarz, I was the author of the exhibition when it first opened in 2004. By academic training I am a cultural anthropologist, with a specialization in Jewish studies and Holocaust studies, and from the late 1980s I came regularly to Poland from my home in the UK in order to undertake field research on the built Jewish heritage out in the villages and county towns of Galicia, or at least the western part of Galicia which is today in Poland (what I refer to below as Polish Galicia). Chris and I worked together from the mid-1990s - he went to all the places I had found and made a documentary photographic record of them, building up an archive of about one thousand photos. My job then was to choose the best photos, arrange them into a set of themes suitable for a museum exhibition, and write captions for them. Very sadly, Chris died in 2007, three years after the museum opened. But the realities documented by his photos continued to change, and so the museum decided in 2016 to update the exhibition and therefore to commission a new photographer to take additional photos which would reflect the changes. Our choice fell on the American photographer and essayist Jason Francisco. It was decided that Jason's photos would not be exhibited separately, but merged into the existing permanent exhibition based on Chris Schwarz's photos. The "Traces of Memory" exhibition currently presents about 150 present-day large-format colour photographs of the Jewish heritage still to be seen in about 50 different towns and villages of Polish Galicia.

The exhibition is innovative in museological terms. It is not about the Jewish history of Galicia, nor is it arranged using conventional chronology, nor is it comprehensive. Rather it is divided into five sections, based on a five-part set of ideas, simple ideas intended to help visitors make sense of the complex realities surrounding the present-day situation of the Jewish heritage seventy-five years after the Holocaust. Let me now briefly outline how these five ideas are represented museologically, the five sections in which the exhibition is organized. The opening section directly presents the popular Jewish stereotype that postHolocaust Poland is nothing but a vast Jewish graveyard. So this section of the exhibition consists entirely of the raw, shocking sight of desolation - for example, photos of ruined synagogues or ruined Jewish cemeteries. The 23 photos on show in this section include the appalling condition of the synagogue in Stary Dzików (a small town near the Ukrainian border) as it looked in the 1990s and of the devastated Jewish cemetery in Czarny Dunajec (a small town near the Slovak border) at that time. ${ }^{2}$ Emphasizing what has been lost by showing the Jewish past of Poland in ruins, and how in that sense the effects of the Holocaust on the built Jewish heritage are still visible, even today, is certainly a powerful and provocative way to begin an exhibition in a Jewish museum. But the next section of the exhibition explicitly contradicts that theme, through photos which offer glimpses of the pre-Holocaust Jewish world that can also still be seen today - for example, synagogues or

grateful to the Museum for the permission to publish here a selection of the photos which were shown on that occasion.

${ }^{2}$ Photos may certainly be understood as representing the realities they stand for at the time they were taken, but over time those realities may change. The synagogue in Stary Dzików has continued to deteriorate since Chris Schwarz took a powerful photo of it in the 1990s, so the exhibition now also includes a photo by Jason Francisco of the same building as it looked twenty years later, in 2016 - simply in order to demonstrate the ongoing effects of deterioration over time. The situation at the Jewish cemetery in Czarny Dunajec, on the other hand, has been completely reversed: in 2020 the site was given a major renovation and proper memorialization, at the initiative of a group of Polish well-wishers led by the celebrity sportsman Dariusz Popiela. 
Jewish cemeteries in reasonably good condition, either not significantly damaged during the Holocaust or having been restored. Unlike the sites shown in section 1, which overall are declining in number nowadays, either because buildings still in ruins are either pulled down or (if possible) restored or partially restored, there is a growing number of photogenic places which illustrate the theme of section 2 . The 34 photos in this section of the exhibition include sites such as the meticulously restored eighteenth-century synagogue in Łańcut; the view from the women's gallery of the magnificent seventeenth-century Izaaka Synagogue in Kraków; and the largely intact Jewish cemetery in Lubaczów with its numerous examples of the art of the traditional tombstone, elaborately carved and with literary inscriptions in elegant Hebrew lettering. All these photos are in utter contrast with those of section 1 of the exhibition.

The third section moves on to the Holocaust, showing 27 photos of the diversity of the settings in which the Holocaust took place, in an attempt to demonstrate that the events of the Holocaust happened everywhere - in open countryside, in city centres, in cemeteries, on hilltops, deep in forests, as well as in the ghettos, slave-labour camps, and the well-known death camps. Illustrative examples of this wide range include an original piece of the wall surrounding the ghetto created by the Germans in Kraków, a mass grave of Jews murdered by the Germans in 1942 in a forest near Jasło, and a representative range of photos taken at the memorial museum at Auschwitz.

As I hope is now clear from the first three sections, the "Traces of Memory" exhibition is not organized chronologically, nor does it include historical photos showing places as they used to be. It is entirely focused on sites as they are today. It opens with the postHolocaust ruins as the key present-day reality, deliberately presenting the result before the cause - which, after all, is how attempts to understand any situation can proceed - and then goes back to what is left of the pre-Holocaust heritage. What follows the Holocaust material in the third section of the "Traces of Memory" exhibition is similarly unexpected: a fourth section focusing on the diverse ways people have responded to that colossal tragedy. This includes both the erasure of memory and also the opposite of that - namely, serious attempts at the memorialization of the Jewish heritage, by Poles as well as by Jews. The exhibition covers a wide range of these highly varied responses, and indeed this is its largest section, with 35 photos. These include, for example, the grave of a Polish Catholic rescuer in the local cemetery in Tuchów with a plaque added to the tombstone dedicated by the survivor expressing her gratitude to this person for having saved her life (in fact the only public sign in this small town that Jews ever lived there); the large monument established in 2004 that covers the entire site of the death camp at Belzec, surely one of the most emotionally powerful Holocaust monuments ever built; a photo of the interior of the restored fifteenth-century Old Synagogue in Kraków, the oldest synagogue building in Poland, which since the 1950s has been an important Jewish museum; and a strong illustration of the erasure of memory - a view of the bus station in the town of Przeworsk, which was built after the war on top of the Jewish cemetery there.

The photos in these first four sections of the exhibition are totally devoid of people, symbolizing the fact of Jewish absence. But the fifth and last section reverses all that. It consists entirely of pictures of the wide range of people who are actively involved today as memory-makers - scholars, Holocaust survivors, souvenir dealers, Hasidic pilgrims, tourists, priests, musicians, and students and university professors, as well as those ordinary local people of Kraków, both Jews and non-Jews, who participate in the activities 
of the city's Jewish Community Centre (established in 2008), and in the massive annual Jewish Culture Festival (established in 1988 by non-Jewish Poles), thereby demonstrating what is widely understood nowadays as the renewal or revival of Jewish culture in Galicia. Its public visibility since 1989 is in strong contrast with the suppression of Jewish culture during the forty years of communist rule in Poland. The 18 photos in this section focus mainly on Kraków, especially Kazimierz, the city's former Jewish district - and they include, for example, the Cheder Café (a locale for Jewish lectures and events in an informal setting, open to all); a lecture to students in the Institute of Jewish Studies at the Jagiellonian University; and a view of a huge, exuberant crowd attending an open-air closing concert of the Jewish Culture Festival.

Altogether, what the "Traces of Memory" exhibition is offering through these five sets of photos is a display of ideas that collectively give an insight into the diversity and the conflicting realities that coexist today. ${ }^{3}$ Visitors to Polish Galicia today move through Kraków and the rest of the region with quite different mental landscapes. For some people, the fundamental truth about present-day Galicia is that after the Holocaust the Jewish heritage is simply in ruins, demonstrating an erasure of the Jewish memory and an overwhelming sense of absence. For others, what is typical is that nowadays there are still a lot of important places of Jewish interest in Galicia which have survived and can offer a powerful sense of the great Jewish civilization that once was. ${ }^{4}$ For yet others the key fact is that more or less everywhere you look are physical reminders of the Holocaust. And for others still, what is typical of the region is that almost everywhere one looks one can see evidence of the efforts people have been making to remember the Jewish past and reconstruct the Jewish heritage. And finally there are some people who focus their attention on the fact that after fifty years of the destruction under Nazism followed by repression under

3 For a full description of the aims and purposes of the original exhibition, together with 74 colour reproductions of the photos on display (all of them taken by Chris Schwarz), see Webber 2009. The second edition of this book (Webber 2018) reflects the exhibition as updated in 2016; it includes 100 photos, of which nearly half were taken by Jason Francisco.

4 There are several good photographic albums focusing more or less just on this approach; for one good example of the genre, see Dylewski 2009, which has been put together by an author well established in the field. It presents material across all of Poland and is arranged town-by-town (in alphabetical order). Its texts do include brief mentions of the Holocaust period, and there are occasional photos of memorial plaques, but its main purpose is to show off the built Jewish heritage, largely in the grand style, still surviving today in Poland. In the whole country, only about 250 pre-war synagogue buildings and prayer-houses (batei midrash) have survived, of which more than sixty are to be found in Polish Galicia. Of these sixty, two are functioning synagogues (both in Kraków), one is a Jewish museum (also in Kraków), and several other synagogues in the city have been restored to the small Jewish community there and used for occasional prayer services (two of these are discussed below). The fate of surviving synagogue buildings across the country covers a wide range: many are used simply as warehouses, others have been converted into use as libraries, art galleries, city archives, and schools. Some have been used for quite inappropriate purposes - as cinemas, fire stations, shops, and restaurants, even in one case (Gorlice) as a bakery, and in another case (Ahavat Re'im in Kraków) as an Orthodox church - usually entailing considerable damage to their original internal structure and paintings. For a basic listing and detailed survey, see Bergman and Jagielski 1990, 1996. One relatively recent case (in 2013), which caused significant concern among Jewish groups worldwide, was the leasing by the Jewish community of Krakow of a fine nineteenth-century beit midrash, complete with wall paintings and Hebrew inscriptions, to a commercial company in Kraków which converted the space into a disco and bar, demolishing the prayer-house's ark for the Torah scrolls and turning that space into a passage onto the street (see http:// www.jewish-heritage-europe.eu/2013/05/09/krakow-beit-midrash-now-turned-into-a-disco/). 
communism there are today clear signs of renewal, revival, and a new public visibility of Jewish culture, accompanied by sustained attempts at healing and reconciliation. ${ }^{5}$

All those five different perspectives are true, all at the same time - there are many different ways to identify what is typical of present-day realities. That is what the "Traces of Memory" exhibition is all about, to present the fundamental point that in a country which witnessed something as catastrophic as the Holocaust, the present-day situation of the Jewish heritage and memory of the Jews is highly complex. To know what that situation consists of today requires familiarity with all these narratives, with all their paradoxes and contradictions. The five sections of the exhibition articulate a multi-dimensional view - in other words, the surviving fragments have been recontextualized in the museum into a plurality of approaches demonstrating that today's realities regarding the Jewish heritage simultaneously encompass great diversity in their range of meanings and the mental landscapes that they represent.

On the other hand - and here I come to my central point - recontextualizing the fragments in a museum exhibition based on those five basic themes has meant reassembling the materials in order to showcase those particular ideas. The exhibition is not a photographic narrative of something already well known. On the contrary, it is a new genre, made by the photographs. By definition, a museum exhibition constructs, reassembles, and demonstrates relationships between scenes and places that could not otherwise be seen together. The meanings that this exhibition is proposing in each section arise specifically out of the juxtaposition of photos that are presented as being about the same basic idea, saying the same thing. Juxtaposing photos in any museum exhibition creates new realities which allow new messages to emerge. That is precisely what can be so useful and indeed provocative about a museum exhibition. ${ }^{6}$

In the "Traces of Memory" exhibition, examples of each of the five sections have been drawn from all over western Galicia (with the exception of the last section on the Jewish revival, which is largely focused on Kraków). The photos of ruins range from Przemyśl in the east to Zator in the west. It certainly makes a strong case to see such photos placed alongside each other. Sometimes (especially in sections 3 and 4) we have put in negative evidence to contradict the main argument of a section. But the exhibition as a whole certainly presents contradictory arguments - for one example, both ruined synagogues and well-preserved or restored synagogues are to be found in the region.

\section{Multiple meanings and multiple narratives}

So it is the coherence of the individual sections which I would like to turn to now. My starting point for this discussion is the basic fact that any one photo can have multiple

\footnotetext{
${ }^{5}$ Probably the best photographic album focusing on this subject is Fishman 2019, based on a temporary exhibition that year at the Galicia Jewish Museum. Chuck Fishman came to Poland in the 1970s and photographed what was widely thought at the time to be the "final chapter" of Polish Jews; but he came back to Poland several decades later, in the years 2013-18, and took photos showing the revival of Jewish life that had come about during his absence. In a striking contrast, Fishman 2019 includes photos of both those two periods.

${ }^{6}$ As regards the representation in a museum context of Polish Jewish culture, probably the key brief text for consultation is Kirshenblatt-Gimblett 2014, reflecting on her experience curating the core exhibition of the Polin Museum of the History of Polish Jews (Warsaw), and reminding us that museums in general can act as major agencies of social and intellectual transformation. This idea builds on her previous work (which included detailed studies of "exhibiting Jews" in world fairs of the nineteenth and twentieth centuries) stressing what she calls the "agency of display," i.e. how detached ethnographic fragments in museum exhibitions show, speak, and do (Kirshenblatt-Gimblett 1998: 6, 17-128).
} 


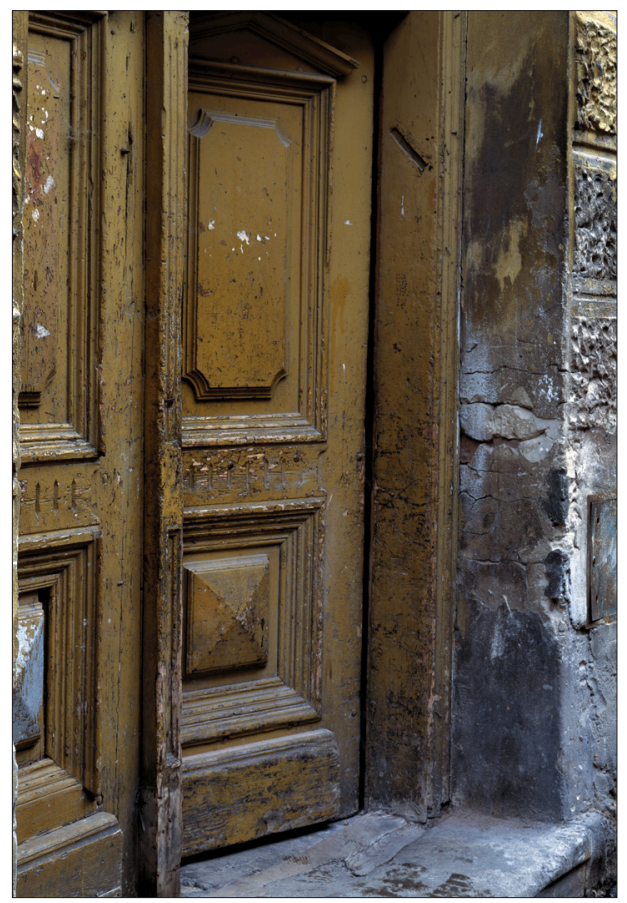

Figure 1. The trace of where a mezuzah once was, seen in Tarnów. ${ }^{9}$

Photograph by Chris Schwarz, mid-1990s.

(c) Galicia Jewish Museum, Kraków. meanings - or at least it can be demonstrated to illustrate more than one idea, whatever the photographer originally intended to show. ${ }^{7}$ To give a simple example, is the trace of a mezuzah (see Fig. 1) to be understood as illustrating a feature of traditional Jewish religious culture - that is, that a Jewish home should have on its doorways a small parchment scroll of handwritten biblical texts, usually inside a protective case of some kind? Or - given that all that is now to be seen in Figure 1 is a scar on the main entry door where the mezuzah used to be - is it to be understood as a small but tragic piece of evidence signifying the deportation and murder of the Jews who used to live in that house? In that case, the trace of a mezuzah on the entry door is a poignant public statement physically marking the absence of Jews from their former homes, and in that sense it belongs to the category of post-Holocaust ruins. Surely it is both these things at the same time. To put it another way, do we evaluate the trace of a me$z u z a h$ in terms of what it originally meant in the pre-war past, or should we relate to its present-day meaning? In fact this particular example is not a complicated issue: it is not an actual mezuzah, which for ritual purposes has to be complete with its parchment scroll; this is a trace of a mezuzah, where a mezuzah used to be. So looking at this photo we can definitely say that it is an example of a ruin, even if it points to another meaning as well. ${ }^{8}$

${ }^{7}$ Pierre Bourdieu (1990: 7) calls this the "surplus of meaning," i.e. over and above the intentions of the photographer, and he presents the case for understanding photography in general as an object of sociological study. However, it is not at all my purpose here to develop a theoretical sociological analysis of the subjectmatter of this paper (on which see for example Vergo 1989, an early landmark publication). Such an analysis, which would entail excursions into museology, heritage studies, and tourism studies (including the tension between "essentialist" and "constructivist" views of Jewish culture in Poland), on all of which there is now a large body of scholarly literature, would carry the reader rather far from the primary ethnography this paper seeks to present. Nor, for the same reason, have I included here references to the similarly large and constantly growing body of literature published on Polish Galicia, especially during the last thirty years, but instead have restricted myself to just a handful of some of the key works.

${ }^{8}$ When the Jews were forcibly expelled from their homes by the Germans (for "resettlement" in another town), they will often have tried to take their mezuzahs with them, for use in their new place (see, for example, Trunk 1979: 175), though if they were being moved to a German-constructed ghetto it was not clear if they would be obliged by Jewish law to have mezuzahs there at all, any more than in a regular prison (thus the view of Rabbi Ephraim Oshry, the author of numerous rabbinical responsa in the ghetto of Kaunas; see Oshry 1983: 95-96, or, for a more elaborate discussion of this issue, Rosenbaum 1976: 87-89).

9 All photographs in this paper come from the "Traces of Memory. Contemporary Look at the Jewish Past in Poland," permanent exhibition of the Galicia Jewish Museum, Kraków (www.galiciajewishmuseum. 


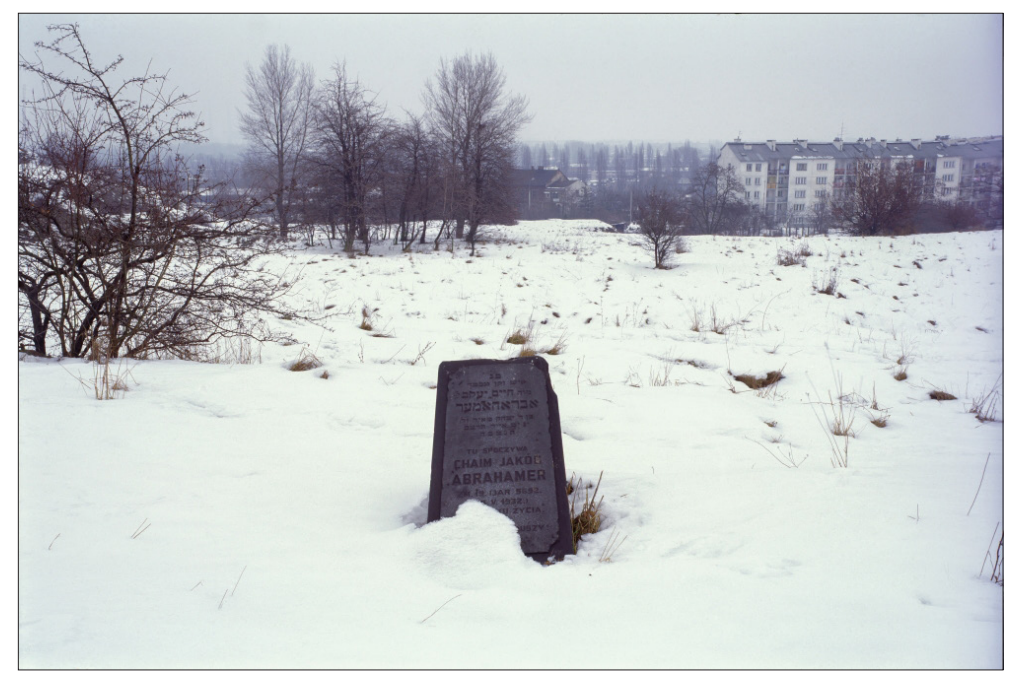

Figure 2. The randomness and complexity of the surviving traces of memory: a single pre-war tombstone at the site of a devastated Jewish cemetery.

Photograph by Chris Schwarz, mid-1990s. C Galicia Jewish Museum, Kraków.

The photo seen in Figure 2, on the other hand, seems to offer an obvious message a tombstone, after all, is just a tombstone. But on closer inspection it in fact turns out to have perhaps the same multiple cultural meanings as the trace of a mezuzah. This view of a pre-war matzevah (the Hebrew term for a Jewish tombstone, widely known in Poland) makes it clear that the setting is inside what is or was a Jewish cemetery. But there are no other tombstones to be seen here. In fact this is the Jewish cemetery of Wola Duchacka in Kraków, which during the German occupation was totally dismantled and its area reused as part of the concentration camp of Płaszów. Płaszów was itself dismantled by the Germans towards the end of the war, when the Russians were approaching, and to this day is a large piece of open parkland, with no trace of the German camp (other than some commemorative monuments). This land is therefore a double graveyard, a graveyard on top of a graveyard, a place that was consecrated for the dignified burial of the dead but was turned into a setting for the deliberate murder of the living. The tombstone of Chaim Abrahamer, who died in 1932, is most probably the only surviving tombstone of the former Jewish cemetery with an original inscription still legible. It is strange to think that there can be such a thing as a survivor of a cemetery, let alone a random, sole survivor. ${ }^{10}$ But apart from this unusual history, what does the fragment mean? Do we understand it as we did the mezuzah trace, as evidence of a person who was buried here in peacetime

org). Exhibition Authors: Prof. Jonathan Webber, Chris Schwarz. Photographs: Chris Schwarz, Jason Francisco. (C) Galicia Jewish Museum

${ }^{10}$ Roma Ligocka, a Holocaust survivor from Kraków and the author of a well-known memoir, has identified it as the grave of her great-grandfather (Ligocka 2002: 288). According to the inscription on the tombstone, he died on 25 May 1932, just a little over a month after the cemetery in this place was officially opened, on 6 April 1932 (for that date, and the background to this new cemetery, see Zbroja 2007: 47-48). What an irony: he was one of the first to be buried in the cemetery, but the last identifiable survivor of it. 
inside a Jewish cemetery - and thus a feature of traditional Jewish culture? Or is it to be understood as post-Holocaust evidence of a deeply tragic past, of what happened to that cemetery during the German occupation? Is it the last trace of a normal, pre-Holocaust Jewish world, or is it a symbol of the catastrophe that engulfed it? There is no simple answer. Once again, it seems to mean both these things at the same time - even if, as a fragment, it cannot, by definition, tell the whole story. Because it is an isolated single tombstone remaining from a cemetery it belongs to the category of ruins and is thus no different, analytically speaking, from the mezuzah trace. But the important thing is that it should certainly be understood in context, as having more than one meaning. I believe that our scholarly job should always be to unpack and report multiple meanings such as these, even if it may be impossible to choose between them. Part of understanding any reality is to be aware of multiple interpretations.

In addition to the stupendous loss of life, the Holocaust totally undermined the stability of former cultural meanings in Poland. Nothing would ever mean the same again. Once one becomes aware of multiple post-Holocaust meanings, one can find them everywhere in present-day Polish Galicia. Consider, for example, the Tempel (Progressive) Synagogue in Miodowa Street in Kraków, founded in the nineteenth century, a photo of which appears in section 2 of the exhibition. The synagogue was badly damaged during the German occupation, but it was in good enough condition to be used for prayer services by Holocaust survivors for a few years after the war; and after 1989 the building was carefully restored by a consortium of local and foreign agencies. But by that time there were not enough regular worshippers among the Holocaust survivors and their descendants left in Kraków to fill this large synagogue for prayer services. So what is this place now? The tourist maps routinely identify this building as a synagogue, and so do the tourist guides. ${ }^{11}$ That is perfectly understandable, given the architecture and the history of the building. But it is not a synagogue in the sense of being regularly used as a synagogue. The Tempel is in practice a former synagogue, and although it is occasionally used as a synagogue when there are very large groups of Jewish visitors (such as during the March of the Living), ${ }^{12}$ this building today is essentially a museum, even if it is not really presented specifically as a museum, which would for example point out its many interesting architectural and artistic features. Or else it is used for general audiences as a concert hall (like during the Jewish Culture Festival), or repurposed even simply as a lecture theatre (for large international conferences, for example). However, for many Jewish visitors, the overriding sensation on being in the Tempel is an awareness of the Holocaust and its legacy of absence, the absence of the worshippers for whom this

11 See for example Legutko-Ołownia 2004: 73-75.

12 The March of the Living is an annual Holocaust Remembrance Day event established in 1988 to enact a Zionist narrative of Jewish history and to promote Jewish identity, and in particular an attachment to the State of Israel. It is an organized march for Jewish teenagers along the road between the Auschwitz main camp and Auschwitz-Birkenau (about $3 \mathrm{~km}$ ), followed by a ceremony and cultural programme there. There are on average about 10,000 participants from around the world, dressed in a distinctive blue uniform and often holding Israeli flags (or even wearing them). They usually stay on in Poland for several days and make group visits to Jewish heritage sites, especially those which evoke tragedy and absence. On the March of the Living in its Polish setting (although it is followed up by the participants proceeding to Israel to celebrate Israeli Independence Day there), see Sheramy 2007. 
place was originally erected. ${ }^{13}$ In short, this place has multiple functions, and therefore multiple meanings.

Much the same could be said about any well-restored synagogue, such as the magnificent, sumptuously decorated eighteenth-century synagogue of Łańcut, with paintings of animals representing spiritual virtues, and arched niches all the way round the walls filled with texts of Hebrew prayers, or even the iconic Rema Synagogue in Kraków, founded in 1553 and the oldest synagogue in Poland still in use..$^{14}$ The Rema (Rabbi Moses Isserles, 1525-72) is famed throughout the (educated) Jewish world for his learned and detailed specifications of Jewish law governing daily life, still considered to this day by Orthodox Ashkenazi Jews as essential for study. His synagogue thus continues to attract many visitors, and amongst them Orthodox Jewish pilgrims who by praying there feel they are connecting with this outstanding luminary. But the Rema Synagogue is more complicated than other restored synagogues, since on weekdays it is treated as a museum (for which visitors have to buy an entry ticket) but on the Sabbath and Jewish religious festivals it functions as a synagogue (and on those days entry is free of charge to worshippers). The building is thus culturally ambiguous, being to this day both a museum and serving as a regular prayer space, notionally for the benefit of a small community of local Jews. Foreign Jewish visitors who arrive with a strong consciousness of the reality of post-Holocaust Jewish absence often assume that there are no living Jews left in Poland at all, and so they must navigate this ambiguity. Tourists interested simply in gazing at the art and architecture of Jewish heritage sites in Poland are astonished to discover this small synagogue full of worshippers at a prayer service on a festival day, when all they want to do is to listen to their tour guide in what they had imagined would be an empty building, and then take photos (something which Jewish law prohibits on a festival day, let alone in a synagogue). Once again, it is the Holocaust which has distorted the meaning of the place - now it is both a synagogue and a heritage site. ${ }^{15}$

13 Jewish visitors who are descendants of members of this synagogue may well have acquired very fond recollections of two remarkable twentieth-century personalities who officiated at prayer services: the outstanding cantor Josef Fischer and the outstanding preacher Rabbi Ozjasz Thon. Crowds used to flock there on festival days to hear Fischer's singing and Thon's sermons, which filled the synagogue with an atmosphere of elevated sanctity. Worshippers were convinced that the only way for mere mortals to taste true festival joy was to hear Fischer and Thon (Geshuri 1959: 347-8).

14 Known in Polish as "Remu" (with the word stress on the penultimate syllable), following a polonized rendering of a local Yiddish pronunciation of the name.

15 The situation in this synagogue is by no means unique: it can be found in many places across Europe where there is a small local post-Holocaust Jewish community still taking care of their built heritage. One interesting example is the ghetto in Venice, the built heritage of which was largely left untouched during the German occupation there - indeed virtually nowhere else in Europe (other than Kraków and Prague) is it possible to see an entire Jewish quarter, dating in part from medieval times, still standing. Venice contains several remarkable old synagogues which, with their original furnishings, including wooden pews and crimson textiles, still look extremely grand and indeed are principally treated as museums, but they are also used for prayer services by the Jewish community there. Photographic albums tend on the whole to document these synagogues as museums, and portray them empty of people, but they may also show them as being in use as synagogues - through photographs either showing prayer-books left open on the pews or indeed with a congregation in attendance. It is an important photographic distinction. Cooperman and Curiel's lavishly illustrated album (1990) includes just four photos that point to the latter (on the front cover and also on 124, 133,138 , and 139), but it is important that they are there at all, illustrating that these places are not just heritage sites, of great importance, but also in use as synagogues. 


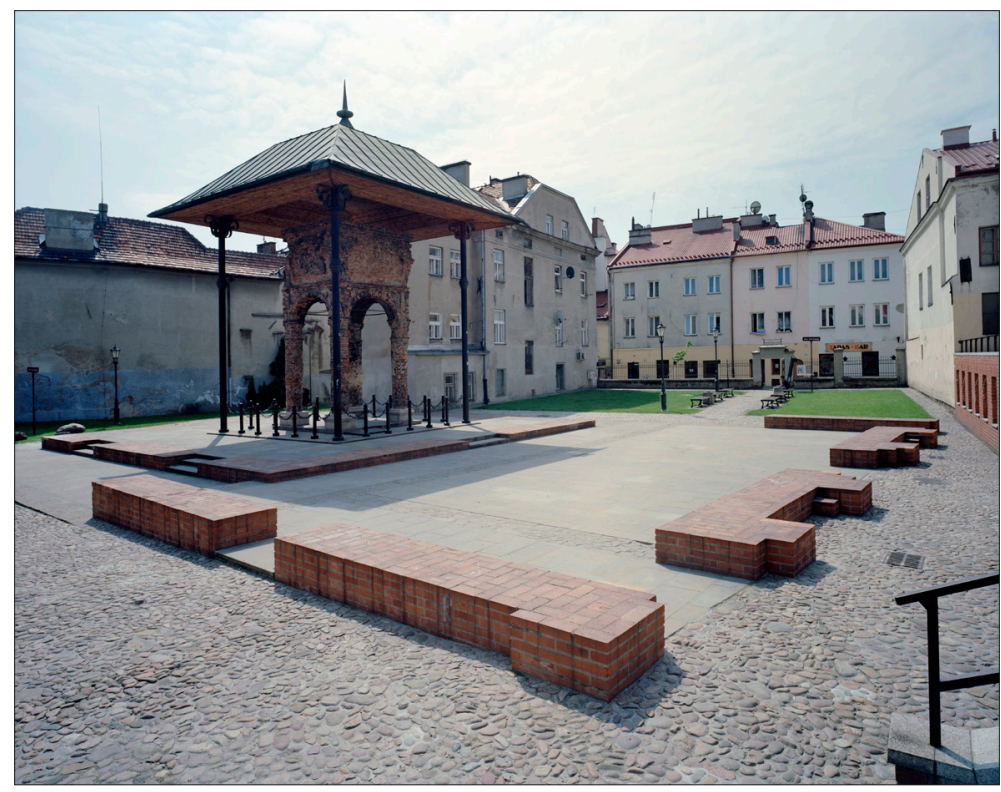

Figure 3. A city centre park in Tarnów memorializes its Jewish heritage.

Photograph by Jason Francisco, 2015. (C) Galicia Jewish Museum, Kraków.

So if such synagogues have multiple meanings, where then should they appear in the "Traces of Memory" exhibition? They are certainly not ruins in a physical sense, and so do not belong with the photos of ruins in section 1 . Rather, I felt that their primary identity, for the purpose of the exhibition, is as Jewish heritage sites, as surviving fragments of the vibrant pre-Holocaust traditional Jewish culture, and so I placed photos of such synagogues in section 2. One photo of the Tempel being used for a concert on the festival of Chanukah, decorated for the occasion with coloured bunting and showing the president of the Kraków Jewish community making a speech there before the orchestra and a large (general) audience, I placed in section 5 of the exhibition, that dealing with the Jewish revival and focusing on portraits of specific noteworthy people. One important photo in section 4, the section devoted to the different ways in which people in Poland cope with their difficult and complex past, is a memorial park in the centre of Tarnów, one block from this city's main market square (see Fig. 3). All that remains of what once was a magnificent seventeenth-century synagogue, burnt down by the Germans in 1939, is the ruin of the vaulted bimah (the central platform in a synagogue for the reading of the Torah), and it has been carefully preserved under a wooden canopy and surrounded by bollards and decorative chains. The bimah has thus been consciously incorporated into the present-day urban space. It has two obvious cultural meanings: it is both a memorial to the destruction of the city's Jews during the Holocaust, but also, through the sympathetic landscaping of the surrounding site as a small park, complete with lawns and seating areas, it functions as a tribute to the substantial pre-war Jewish contribution to the social and economic life of the city - and nowadays there are regular concerts and 
other Jewish cultural performances held in this space. ${ }^{16}$ In other words, the same place can be shown to have two quite different cultural meanings. By positioning them differently in the exhibition and captioning them differently one can present these different realities. This is a good example of how a museum exhibition constructs the ideas and reassembles the relationships between photos or artefacts that it wants to present.

The whole exhibition is, of course, devoted to a post-Holocaust understanding of the surviving fragments of the built Jewish culture as they exist today. Nowhere in western Galicia today, not even in Kraków, can one find traditional Jewish life with natural, organic links with what went before. That life, and the society that produced it, were totally destroyed, and the best we have today is a reconstruction based on those fragments which happened to survive, supported by a small incomer Jewish community which includes some local people who have recently reclaimed their Jewish identity. If a particular place possesses multiple meanings today, that is because of the total cultural displacement created by the Holocaust and its long-term after-effects. Under such circumstances it is inevitable there would be multiple meanings. The surviving fragments to be seen today, especially in Kraków's former Jewish quarter in Kazimierz, started out as having been originally produced in the context of traditional Jewish culture; they were damaged by the Germans, who often used synagogue buildings as warehouses or as stables for their horses; then they fell into abandonment and neglect during forty years of communism, and today they are subject to being reconstructed and reinvented as Jewish heritage sites and indeed, in some cases, commercialized. ${ }^{17}$ No wonder they have multiple meanings. After such a complex history, the apparent details of restored heritage sites often cannot be taken literally.

A good example of this is a restored Jewish cemetery, of which there are several photos in the exhibition. During the war, very many Jewish cemeteries in Galicia were devastated, and their tombstones were removed by the Germans for re-use as paving stones. Today, it sometimes happens that in consequence of local civic initiatives a number of such tombstones are returned to the cemetery by Poles acting out of a sense of goodwill. But where exactly to re-erect them? The problem is that the cemetery registers listing the precise position of the individual named graves often did not survive, usually making it impossible to re-erect those returned tombstones above the actual graves they were originally intended to memorialise. A very common solution to this problem of memorializing a devastated Jewish cemetery no longer in use by a living Jewish community in the locality has often been to turn it into what in effect is a lapidarium - a collection of surviving tombstones, arranged in neat rows as if in a museum of tombstones. One interesting example is the Old Cemetery in Kraków, adjacent to the Rema Synagogue, and where the Rema himself is buried, along with many other distinguished rabbis. ${ }^{18}$ Another

${ }^{16}$ For a photo of one such concert at the bimah, see Bartosz 2009: 359. Adam Bartosz was the director for more than thirty years (1980-2012) of the museum in Tarnów, with a long personal involvement in initiating and organizing exhibitions, memorials, and civic events promoting the city's Jewish heritage.

${ }^{17}$ For a detailed survey, based on a full-scale monograph on the subject, see Murzyn-Kupisz 2009.

18 The Germans used the cemetery as a garbage dump and also destroyed many of the tombstones. Shortly after the war, the Jewish community that was re-established in Kraków made it a priority to replace the missing tombstones, but during further renovations in the late $1950 \mathrm{~s}$, several hundred tombstones were unearthed from under the top-soil, including many which had previously been considered as missing - with the result that some rabbis now had two tombstones. Other than the grave of Rabbi Isserles, the location of 
example is the restored cemetery in the rural village of Brzostek (near Jasło). ${ }^{19}$ In most such cases the number of intact tombstones found were not enough to fill the whole area of the cemetery, leaving large empty spaces. This is true of both cemeteries mentioned here, which were certainly full before the war. What was done in the Old Cemetery in Kraków (and elsewhere) was to collect together fragments of smashed tombstones and re-erect them in the form of a wall - a vertical lapidarium, as it were. This is certainly a powerful memorial to the destroyed culture and the vandalism of the Holocaust. But the point I want to make here is that this restoration and reconstruction do not convey more than the beginning of an idea of what these cemeteries once were. Their meaning has changed. What one sees today in such places are sites which do not fully mean what they were originally intended to mean. One cannot take the details of such restorations literally. This is not at all intended as a criticism of the restoration projects - it has to be assumed that the restorers did their job as best they could, with the materials they had to hand. But nevertheless what we have ended up with in such cases is a representation of the original, not the original itself. It may make the appearance of such places hard to fully understand - even if the casual visitor may not necessarily register that. Our job as scholars is surely to help people get beyond surface impressions so as to understand reality, particularly when its meaning is not obvious.

An especially strong example of this is the site of Auschwitz, which has been a Polish state museum since 1947 and is unquestionably the largest and most important museum today in western Galicia; in 2019 it received well over two million visitors. ${ }^{20}$ Many of the surviving buildings and other structures in Auschwitz, which visitors understand as authentic, are in fact reconstructions, albeit done to a high standard, with patient attention to detail. One important exception is the gas chamber in the main camp of Auschwitz (the Stammlager, or Auschwitz I), which was restored in the early years of the museum; the restoration is so full of historical inaccuracies that the museum actually makes that clear in the text of the information panel outside the building. But otherwise there is quite enough in the immense size of the territory of the museum (approximately 450 acres, including Auschwitz I and Auschwitz II-Birkenau) to give visitors on a specific route through the sites a good idea of what the place looked like during the war in reliable detail (including the restored prisoner barracks, watchtowers, barbed-wire fences, and the railway line in Birkenau). ${ }^{21}$ On the other hand, the site is full of ruins - especially

which was correctly identified, the community was unable to solve the problem, so the tombstones which had been discovered were simply placed in rows (Legutko-Ołownia 2004: 54-5). Very many have beautifully carved decorations and elaborate inscriptions in elegant Hebrew lettering, making this cemetery an exceptional site of Jewish cultural heritage.

19 This was a private initiative in 2009, which through cultural diplomacy became a project of the whole village, manifested in the return of about sixty tombstones from local farms. The episode became the subject of an award-winning film; for full details see Webber 2020.

${ }^{20}$ In the museum's official annual report for 2019, the figure given (at page 25) is 2,320,000 visitors (http://auschwitz.org/en/museum/museum-reports/). Visitor numbers have been growing exponentially year on year: the 2019 figure is nearly five times the figure given for 2001 (Ibid.)

${ }_{21}$ Not all the prisoner barracks in Birkenau have been restored, nor all the barbed-wire fences, as noted immediately below. But the process of turning the Auschwitz I camp into a museum involved a series of historical distortions, as described by the architectural historian Robert Jan van Pelt (van Pelt and Dwork 1996: 359-366). It seems to be intact and unchanged, but it is quite different from the camp the Soviets liberated in 1945. For example, "a misconstruction of history begins right in the parking lot: visitors think they have ar- 
the ruins of the buildings containing three of the main gas chambers and crematoria in Birkenau, which were destroyed on German orders towards the end of 1944 as Soviet forces were approaching in order to try to conceal the evidence of their crimes. The fact that these buildings are in ruins is therefore a definite part of the wartime history of Auschwitz, which is one reason why there has been no attempt by the museum to reconstruct and restore them to what they originally looked like. The same is true as regards the ruins of one other gas chamber and crematorium which was destroyed by Jewish prisoners during an uprising in October 1944. But Birkenau is also full of ruins with quite a different history: very many of the prisoner barracks there simply fell into ruin after the end of the war, when local Poles entered the former camp to help themselves to building materials, which were in short supply at that time,,$^{22}$ and then these abandoned barracks slowly deteriorated over the passage of time (see Fig. 4). This photo was taken some distance away from the main visitor route through Birkenau, which is why the museum has not replaced the barbed wire here, as has been done elsewhere at the site. These ruins, unlike the ruins of the gas chambers, are not part of the wartime history of Auschwitz; they tell another story. But the fact that Birkenau is so full of ruins makes its appearance today hard for the ordinary visitor to understand. The ruins came about as a result of direct interventions by Germans and by Jews and by Poles, as well as by the passage of time since the end of the war more than seventy-five years ago. It is a profoundly ambiguous multiple narrative, and that is not something that the museum is anxious to communicate to visitors, who will in any case not easily understand this strange landscape. Or, if they do, it is likely that they are interested only in the wartime part of the Auschwitz story that is, the ruins brought about only by the Germans or the Jews. ${ }^{23}$

One other rather important set of examples regarding multiple narratives needs to be mentioned, and that relates to the provocative question of whether Poles and Jews have any shared sense of their respective sufferings during the war. Do Jewish victimhood during the Holocaust and Polish victimhood during the German occupation belong together? Or do they form two quite separate (even perhaps unconnected) narratives? The truth is that for at least forty-five years after the Holocaust the two narratives were not merely separate and unconnected: there was a bitter division between them, focusing particularly on the issue of Polish co-responsibility for the genocide of the Jews undertaken by Germans during the occupation - the Polish apologetic stress on heroism and martyrdom on one side versus Jewish condemnation of what they see as a fundamentally antisemitic Polish society on the other. At the end of the 1980s, however, a major breakthrough into dialogue began, as scholars on both sides initiated approaches to open up

rived at the periphery of Auschwitz I; in fact, they are already in the middle of the camp as it existed in 1945" (Ibid.: 359-360). This is because the camp had been extended in 1942, but the territory was excluded from the museum, and its barracks used by the Polish army and housing for the local population. The official tours of the site conventionally begin with the iconic "Arbeit macht frei" gate - but this gate did not have a central role in the history of Auschwitz, as we have been led to believe (Ibid.: 360-362). The Auschwitz museum is in other words like any other museum: it has commodified and repackaged what it wishes to present to visitors.

${ }^{22}$ Huener 2003: 64-65. By the end of 1946 as many as $60 \%$ of the buildings, mainly in Birkenau, had been destroyed by this looting (Ibid.: 263, n. 58).

${ }^{23}$ On the complex multiple narratives engendered by the Auschwitz site, notably the Polish narrative of national martyrdom and the Jewish narratives of diaspora victimhood followed by post-Holocaust Jewish survival and post-Holocaust Jewish achievements in the State of Israel, see Webber 2016. 
topics previously considered too sensitive, even taboo, for detached discussion. ${ }^{24}$ The debate surfaced in numerous contexts, including monuments at original Holocaust sites.

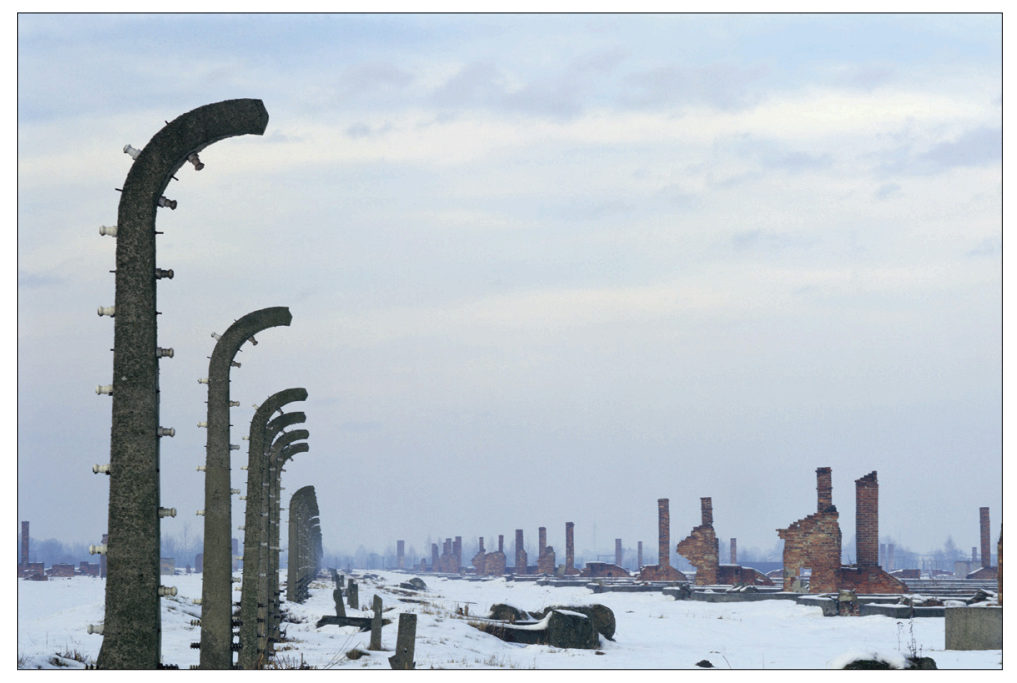

Figure 4. Ruins of prisoner barracks and the disappearance of barbed wire in a sector of Birkenau off the main visitor route through the site.

Photograph by Chris Schwarz, mid-1990s. (C) Galicia Jewish Museum, Kraków.

One Auschwitz example will have to suffice here. Approximately 75,000 ethnic Poles were murdered in Auschwitz, certainly a large number in itself but a mere $8 \%$ or so of the total number of victims of that notorious camp, of whom over $90 \%$ were Jews. ${ }^{25}$ Some of the cremated ashes of both Jews and Poles were dumped by the Germans onto a field at the back of Birkenau, and in the early 1980s a group of Polish students took the initiative to erect simple wooden crosses there in order to memorialize them. International Jewish organizations, inflamed by the presence of a Carmelite convent established in 1984 in an old building next to the main camp of Auschwitz, could not accept the presence of Christian symbols at the site of this massive Jewish graveyard, the very epicentre of the

${ }^{24}$ There is very substantial literature on all aspects of this. The breakthrough was marked by a series of landmark scholarly conferences, bringing together both Polish and Jewish scholars, notably one held in Oxford in 1984 and followed up by the founding of the annual Polin: Studies in Polish Jewry, whose editorin-chief to this day is the scholar activist Antony Polonsky (by 2020 thirty-two volumes have been published). See for example an important set of historical papers in Zimmerman 2003; another set of papers, focusing on dialogue, can be found in Cherry and Orla-Bukowska 2007. The Polish NGO Forum for Dialogue, mentioned in the latter volume, has grown today into the largest grassroots organization in Poland specializing in building groups and networks devoted to encouraging and empowering new connections between Poland and the Jewish people; they have been working in as many as three hundred towns across the country (see www.dialog.org.pl).

25 These figures are from the authoritative work by Franciszek Piper (1991), who as the head of the historical research department of the Auschwitz-Birkenau State Museum made an in-depth study of the issue. 
Holocaust, and they demanded the removal of those crosses, which they saw as a sign of antisemitic Christian triumphalism. They seemed unaware of the fact that the students had also erected wooden Stars of David in this field. ${ }^{26}$ The museum, anxious not to offend its visitors or to involve itself in issues relating to the spiritual ownership of the site, in any case preferred to avoid religious symbols altogether, and in its exhibitions it presents the generalized historical facts of the mass murder, brutality and suffering, largely bypassing the existence of these multiple narratives, so far as it is able to do so. So it decided to remove both the crosses and the Stars of David, and instead erected four tombstone-like monuments in black granite (in four different languages) memorializing the victims of the Nazi genocide simply as "men, women, and children" - that is, in universalist language that has no explicit mention of anything about their cultural identity, such as their religion or ethnicity, even if the four languages chosen (Polish, English, Hebrew, and Yiddish) rather give the game away.

The challenge to the Auschwitz museum to rely on a universalist approach has a long history dating back to the Stalinist period in early post-war Polish history. ${ }^{27}$ Essentially, in those early days, the inscriptions on the monuments erected by the state authorities at sites of mass murder throughout Polish Galicia tended to identify the victims simply as victims of fascist ("Hitlerite") terror. In a clearing in a forest in Zbylitowska Góra, a few miles outside Tarnów, there is a large monument marking the horrific mass murders of as many as 10,000 people, approximately 8,000 Jews and 2,000 ethnic Poles. ${ }^{28}$ The Jews and the Poles had been brought to the place on separate occasions, and at each mass shooting the victims were shot into their own mass grave. On the back of the monument is a plaque giving that global figure of 10,000 victims, who are described simply as Polish citizens, without mentioning that breakdown of the total figure. However, near this monument is a series of separate mass graves. The mass graves of the Polish Catholic victims have their own Catholic monuments, and likewise there are Jewish monuments at each of the mass graves of the Jewish victims. None of those monuments refers to the existence of other victim groups, so there is no sense at the mass graves themselves of shared victimhood. For example, there is a small Jewish monument at the mass grave of 800 children murdered here; it has inscriptions in Hebrew, Yiddish, and Polish, and refers only to those 800 children. The photo of this place that we have on display in the "Traces of Memory" exhibition is not a close-up of that Jewish monument but rather the

${ }^{26}$ Much has been written about this episode. James Young (1993: 144-150) has a useful brief survey of the bitter dispute surrounding the convent, as well as a photo showing the crosses and a (crucified) Star of David alongside each other (Ibid.: 151). See also Van Pelt and Dwork 1996: 366-373 for their (rather different) brief survey of the dispute and including a photo of the field, in this case with several Stars of David (none of them nailed to a cross) on p. 371.

${ }^{27}$ For a detailed account of the Auschwitz museum during that period, see Huener 2003, especially ch. 3 (covering the years 1947-54): choreographed commemorative ritual with hyperbolic Cold War rhetoric became the norm. In 1950 the museum's exhibition was changed so as to emphasize socialist heroism, not tragedy - Auschwitz was not just a monument to Poland's martyrs but a symbol of strength and wartime victory (the indestructible power of the Polish nation and total victory over fascism). The Holocaust was completely marginalized, the product, as Huener says, of a "studied ignorance" (Ibid.: 78), leaving the Jewish victims of Auschwitz to be treated simply as citizens of their respective countries of origin. The approach has had long-term consequences.

${ }^{28}$ For these figures see for example the Virtual Shtetl portal of the Polin Museum of the History of Polish Jews (Warsaw), https://sztetl.org.pl, s.v. Zbylitowska Góra. 
one seen in Figure 5 - it contextualizes the children's monument with the main monument, for the explicit purpose of my being able to draw attention in the caption to the question of shared victimhood and the underlying issue of multiple narratives. ${ }^{29}$ That is one of the questions explicitly raised in section 4 of the exhibition, whereas the photo of the mass grave itself is on display in the Holocaust section (section 3). This series of photos of this place of massacre certainly makes it very clear how there may be multiple pasts at a single place, overlapping and sometimes contradictory, invoking different kinds of story-telling.

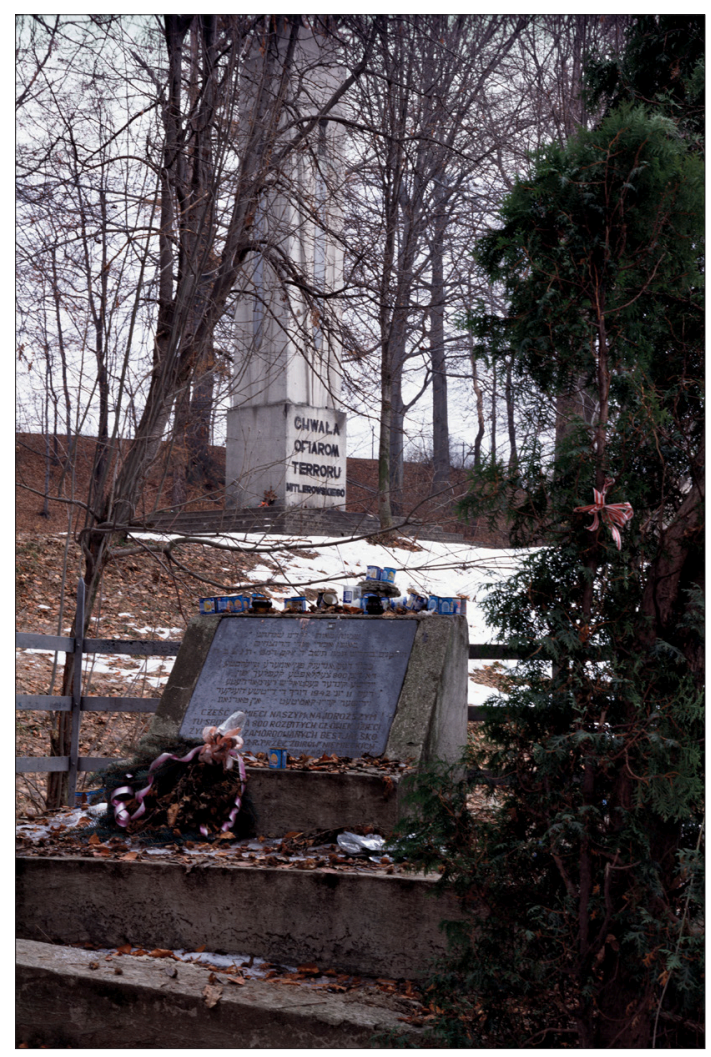

Figure 5. Two monuments - two narratives, in uneasy coexistence. At the site of mass murders in Zbylitowska Góra, near Tarnów.

Photograph by Chris Schwarz, mid-1990s. C Galicia Jewish Museum, Kraków.

${ }^{29}$ For further material on the issues raised by this photo, see Webber 2009: 164-165. 


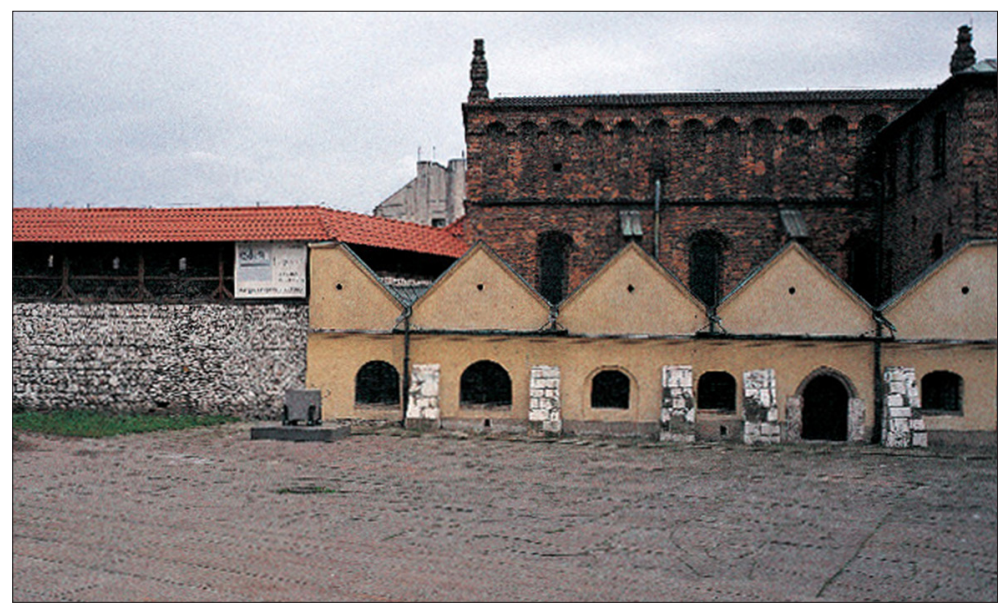

Figure 6. A small monument marking the murder by the Germans of thirty Poles in front of the Old Synagogue in Kraków, the oldest surviving synagogue building in Poland.

Photograph by Chris Schwarz, 1998. C Galicia Jewish Museum, Kraków.

Multiple narratives mean that the same place can mean different things to different people with their different mental landscapes. Most Jewish visitors will understand the photo in Figure 6 as simply a general view of the exterior of the Old Synagogue in Kraków. They have not come to this specific place in order to learn about Polish martyrdom during the Second World War. So it is unlikely that they will even notice the small monument just in front of the building on the left, which is in memory of thirty Poles who were shot by the Germans at this spot in October 1943; the monument has a list of their names carved into the stone. This photo, and indeed this place, certainly suggests multiple narratives. But Jewish visitors returning to Poland as their country of ancestral origin attempting to reconnect with their imagined past, go with their tour guides from Jewish memorial place to Jewish memorial place, ignoring the space in-between as of no intrinsic interest to them. Some of them come with a survivor who can tell them about things which are no longer to be seen at all, such as the Jewish personalities who once lived there, the Jewish grocery store, the Jewish library, or the Jewish fish market. All that has disappeared, except for a few fragments. The rest has to be left to the imagination, fed by the stories of the survivors and guides. However, once a year, during the Jewish Culture Festival, this area in front of the Old Synagogue is used as the stage for musicians playing at the open-air concert marking the Festival's finale. In other words, the architectural environment here is recast as a prop for a stage-set (complete with dramatic stage-lighting), specifically encouraging the imagination to see this building and the space in front of it as a genuine theatre of memory for the celebration of Jewish culture..$^{30}$

${ }^{30}$ The building "explains" the theatricality of the event, animates it, demonstrates that the theatre really belongs to the setting, and in this way is made meaningful for the concert. For a theoretical discussion of how objects can be treated as if they are "actors" and thus "animated" by knowledge, see for example Kirshenblatt-Gimblett 1998: 3. 
Otherwise, empty spaces are usually ignored by visitors, though in the post-Holocaust reality empty spaces may in fact be full of meaning, indicating or representing absent presence. To illustrate this idea in the "Traces of Memory" exhibition, I chose to have just two photos, both of them on display in section 1 (ruins). One is of a large empty space in Oświęcim. Like empty spaces in many provincial town centres in Poland (sometimes used as car parks), it is in fact where the town's main synagogue used to be. The synagogue in Oświęcim was destroyed by the Germans in November 1939; a memorial park is at last being planned for this space. ${ }^{31}$ The other photo shows the market square in the small provincial town of Biecz, completely empty of people (see Fig. 7). There was a synagogue in this square, and the two entry doors to this former synagogue (one door for the men, one door for the women) can be clearly seen in the centre of the photo. Before the war the Jewish community of Biecz comprised about 650 people, 18 per cent of the inhabitants; ${ }^{32}$ the market square would have been full of Yiddish-speaking Jewish traders. But in this photo, taken early one winter morning, no one is to be seen. The sound of Yiddish has gone. In that sense it is in saddening contrast with what was here before. The photo is intended to provide a photographic illustration of the invisible mental landscape dominated by an awareness of the legacy of Jewish absence. In that sense it is a metaphorical image, an attempt to take a present-day photo representing part of the meaning and the consequences of the Holocaust.

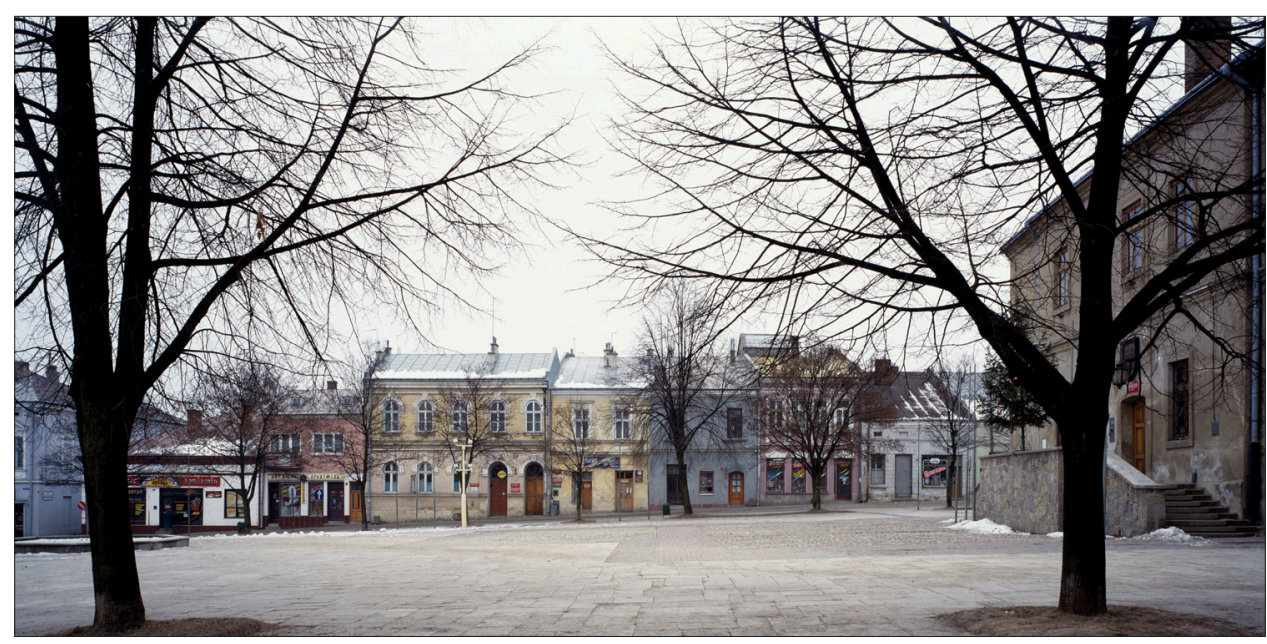

Figure 7. The post-Holocaust reality of Polish Galicia: a town square empty of Jews. Photograph by Chris Schwarz, mid-1990s. C Galicia Jewish Museum, Kraków.

31 See "Poland: Memorial park commemorating the destroyed Great Synagogue in Oświęcim, the town where the Nazis built Auschwitz, wins award - Jewish Heritage Europe" (jewish-heritage-europe.eu, 15.09.2020).

32 For the figures see Spector 2001: i, 143. For western Galicia this encyclopaedia includes only very condensed versions of longer studies published in Hebrew by Yad Vashem in the 1980s in its Pinkas Hakehilot: Polin series. 
I hope that these examples give adequate illustration of my main point that museum exhibitions construct the ideas they want to represent, in this case relying on the inherent multivocality of the photos. Those photos of the "Traces of Memory" exhibition are in any case not intended to provide a comprehensive report or a holistic view about the totality of the Jewish heritage of western Galicia. The photos are just some samples pointing to quite complex realities. That is why the exhibition is called "Traces of Memory." Every place is different from the next one a few kilometres away. Some places today show signs of an energetic approach to recovering their Jewish heritage; other places show little or no such thing. The surviving fragments of pre-war Jewish culture on display in the exhibition are not at all typical of anything except themselves - with the exception of Kraków, they do not relate to the density of pre-war Jewish culture in a particular locality. Some places, such as Dukla or Tarnobrzeg, with a very high percentage of Jews in their pre-war population, are today relatively poor in their density of surviving post-Holocaust fragments. But the five sections of the exhibition are intended to collectively remedy any single perspective or stereotype and instead put forward a sense of the multi-layered present-day realities relating to the Jewish heritage.

\section{BIBLIOGRAPHY}

Bartosz, A. (2009), This Was the Tarnów Shtetl, in: M. Murzyn-Kupisz and J. Purchla (eds.), Reclaiming Memory: Urban Regeneration in the Historic Jewish Quarters of Central European Cities, Kraków: 343-62.

Bergman, E., and J. Jagielski (1990), The Function of Synagogues in the PPR, 1988, in: A. Polonsky (ed.), Polin: Studies in Polish Jewry 5: 40-49.

Bergman, E., and J. Jagielski (1996), Zachowane synagogi i domy modlitwy w Polsce: Katalog, Warszawa.

Bourdieu, P. (1990), Photography: A Middle-Brow Art, trans. Shaun Whiteside, Cambridge.

Cherry, R., and A. Orla-Bukowska (eds.), (2007), Rethinking Poles and Jews: Troubled Past, Brighter Future, Lanham, MD.

Cooperman, B.D., and R. Curiel, with photographs by G. Arici (1990), Il Ghetto di Venezia, Venezia.

Dylewski, A. (2009), Zabytki żydowskie w Polsce, Bielsko-Biała.

Fishman, C. (2019), Portret Żydów polskich / A Portrait of Polish Jews, 1975-2018, Kraków.

Geshuri, M.S. (1959), Cantors and Cantorial Music in Krakow (Heb.), in: A. Bauminger, M. Busak, and N.M. Gelber (eds.), The Book of Kraków: An Ancestral Jewish Town (Heb.), Jerusalem: 344-351.

Huener, J. (2003), Auschwitz, Poland, and the Politics of Commemoration, 1945-1979, Athens, OH.

Kirshenblatt-Gimblett, B. (1998), Destination Culture: Tourism, Museums, and Heritage, Berkeley, CA.

Kirshenblatt-Gimblett, B. (2014), “Theater of History,” in B. Kirshenblatt-Gimblett and A. Polonsky (eds.), Polin: 1000 Year History of Polish Jews, Warsaw: 19-35.

Legutko-Ołownia, A. (2004), Kraków's Kazimierz: Town of Partings and Returns, Kraków.

Ligocka, R. (2002), The Girl in the Red Coat: A Memoir, trans. M. Bettauer Bembo, New York.

Murzyn-Kupisz, M. (2009), Reclaiming Memory or Mass Consumption? Dilemmas in Rediscovering the Jewish Heritage of Kraków's Kazimierz, in: M. Murzyn-Kupisz and J. Purchla (eds.), Reclaiming Memory: Urban Regeneration in the Historic Jewish Quarters of Central European Cities, Kraków: 363-96.

Oshry, E. (1983), Responsa from the Holocaust, trans. Y. Leiman, New York. 
Piper, F. (1991), Estimating the Number of Deportees to and Victims of the Auschwitz-Birkenau Camp, Yad Vashem Studies 21: 49-103.

Rosenbaum, I.J. (1976), The Holocaust and Halakhah, [Brooklyn, NY] Ktav.

Sheramy, R. (2007), From Auschwitz to Jerusalem: Re-enacting Jewish History on the March of the Living, Polin: Studies in Polish Jewry 19: 307-325.

Spector, S. (ed.), (2001), The Encyclopedia of Jewish Life before and during the Holocaust, 3 vols., Jerusalem-New York.

Trunk, I. (1979), Jewish Responses to Nazi Persecution: Collective and Individual Behavior in Extremis, New York.

Van Pelt, R.J., and D. Dwork (1996), Auschwitz: 1270 to the Present, New Haven-London.

Vergo, P. (ed.), (1989), The New Museology, London.

Webber, J. (2009), with photographs by C. Schwarz, Rediscovering Traces of Memory: The Jewish Heritage of Polish Galicia, Oxford (for the Galicia Jewish Museum, Kraków).

Webber, J. (2016), The Kingdom of Death as a Heritage Site: Making Sense of Auschwitz, in: W. Logan, M.N. Craith, and U. Kockel (eds.), A Companion to Heritage Studies, Malden, MA: 115-132.

Webber, J. (2018), with photographs by C. Schwarz and J. Francisco, Rediscovering Traces of Memory: The Jewish Heritage of Polish Galicia (second edition of Webber 2009), London (for the Galicia Jewish Museum, Kraków).

Webber, J. (2020), Cultural Diplomacy in Holocaust Memory Work: A Polish Village Case Study, in: C. Schallié, H. Thorson, and A. Van Noord (eds.), After the Holocaust: Human Rights and Genocide Education in the Approaching Post-Witness Era, Regina, Saskatchewan: 261-88.

Young, J.E. (1993), The Texture of Memory: Holocaust Memorials and Meaning, New Haven-London.

Zbroja, B. (2007), Forgotten Heritage: The Architecture of Jewish Kraków, in: J. Purchla and A. Skotnicki (eds.), A World before a Catastrophe: Kraków's Jews between the Wars (bilingual PolishEnglish edn.), Kraków: 43-52.

Zimmerman, J.D. (ed.), (2003), Contested Memories: Poles and Jews during the Holocaust and Its Aftermath, New Brunswick, NJ. 